\title{
META ANALISIS UPAYA PENINGKATAN HASIL BELAJAR PEMBELAJARAN TEMATIK DI SEKOLAH DASAR
}

\author{
Aminah \\ Dosen Program Studi Pendidikan Guru Sekolah Dasar FKIP Universitas Almuslim \\ Email: amimhdp@gmail.com
}

Diterima 11 Juni 2021/Disetujui 25 Juni 2021

\begin{abstract}
ABSTRAK
Penelitian ini bertujuan untuk mengetahui peningkatan hasil belajar pembelajaran tematik siswa sekolah dasar melalui metode meta analisis. Penelitian ini menggunakan metode desain meta analisis, yaitu kajian atas sejumlah hasil penelitian dalam masalah yang sejenis. Unit analisis dalam penelitian adalah dokumen tertulis tentang pembelajaran tematik berupa artikel yang diambil secara purposive berdasarkan kesesuaiannya dengan tema penelitian. Instrumen penelitian menggunakan human instrument. Setelah fokus penelitian menjadi jelas, dikembangkan instrumen penelitian sederhana yang dapat melengkapi data dan membandingkan data yang ditemukan sebelumnya. Populasi penelitian adalah dokumen tertulis, berupa buku, artikel jurnal, dan laporan penelitian. Sampel penelitian diambil dengan teknik purposive sampling, karena data yang ingin diperoleh ditentukan atas kesesuaiannya dengan tema penelitian. Teknik pengumpulan data menggunakan teknik dokumentasi. Analisis data menggunakan analisis data kuantitatif dengan prosentase dan analisis data kualitatif untuk data hasil kajian naratif terhadap penelitian yang ditemui. Berdasarkan hasil dan pembahasan penelitian, disimpulkan bahwa pembelajaran tematik dapat diajarkan dengan berbagai model, strategi, dan media pembelajaran, sehingga dapat meningkatkan hasil belajar siswa SD. Oleh karena itu, pembelajaran tematik yang dikemas dalam aktivitas pembelajaran taktik secara kognitif berperan dalam meningkatkan kemampuan berpikir siswa, kemampuan pengambilan keputusan, serta transfer dalam sebuah permainan.
\end{abstract}

Kata kunci: meta analisis, hasil belajar, pembelajaran tematik

\section{PENDAHULUAN}

Pembelajaran tematik merupakan model pembelajaran terpadu yang menggunakan tema untuk mengaitkan beberapa mata pelajaran, sehingga dapat memberikan pengalaman bermakna kepada siswa. Pembelajaran tematik mengajak siswa untuk memahami konsep-konsep yang dipelajari melalui pengalaman langsung dan menghubungkannya dengan konsep lain yang sudah dipahaminya.

Forgaty merupakan salah satu pakar pembelajaran yang mengembangkan pemebelajaran tematik. Forgaty (1991), menyatakan bahwa model pembelajaran tematik disebut model webbed, yaitu model yang paling popular dalam pembelajaran terpadu. Model pembelajaran tematik bertolak dari pendekatan tematis sebagai pemadu bahan dan kegiatan pembelajaran.

Oleh karena itu, dalam hubungan ini tema dapat mengikat kegiatan pembelajaran, baik dalam mata pelajaran tertentu maupun lintas mata pelajaran. Maka, pembelajaran tematik dipandang sebagai salah satu pendekatan pembelajaran yang dapat mengaktifkan siswa dalam proses pembelajaran dan meningkatkan kemampuan siswa dalam pembuatan keputusan (Ibnu Hajar, 2013:23).

\section{METODE PENELITIAN}

Penelitian ini menggunakan metode desain meta analisis. Meta analisis merupakan kajian atas sejumlah hasil penelitian dalam masalah yang sejenis. Unit analisis dalam penelitian adalah dokumendokumen tertulis tentang pembelajaran tematik berupa artikel yang diambil secara purposive berdasarkan kesesuaiannya dengan tema penelitian. Instrumen dalam penelitian ini menggunakan human instrument. Setelah fokus penelitian menjadi jelas, maka akan dikembangkan instrumen penelitian sederhana yang dapat melengkapi data dan membandingkan kembali data yang telah 
ditemukan sebelumnya. Populasi dalam penelitian ini adalah semua dokumen tertulis buku, artikel jurnal, dan laporan penelitian. Sampel penelitian diambil menggunakan teknik purposive sampling, karena data atau informasi yang ingin diperoleh dari sampel ditentukan berdasarkan kesesuaiannya dengan tema penelitian. Teknik pengumpulan data menggunakan teknik dokumentasi. Analisis data yang digunakan adalah analisis data kuantitatif dengan prosentase dan analisis data kualitatif untuk data-data hasil kajian naratif terhadap penelitian-penelitian yang ditemui.

\section{HASIL DAN PEMBAHASAN}

\section{Hasil Penelitian}

Penelitian tentang pembelajaran tematik yang diperoleh sebanyak 12 penelitian, yang berasal dari berbagai sumber, yaitu artikel (hasil penelitian) dalam jurnal hasil penelitian dan laporan penelitian. Adapun secara umum, data tersebut didapatkan dengan mengunduh dari internet.

\section{Meta Analisis Berdasarkan Tujuan Penelitian}

Tujuan penelitian pembelajaran tematik yang diperoleh berkisar pada peningkatan hasil belajar siswa pada pembelajaran tematik dengan mengembangkan berbagai model, strategi dan media. Hasil belajar yang ditingkatkan berupa kognitif, afektif dan psikomotorik. Berdasarkan kajian terhadap 12 penelitian diperoleh data sebagai berikut:

Tabel 1. Tujuan Penelitian

\begin{tabular}{clcc}
\hline No. & \multicolumn{1}{c}{ Tujuan Penelitian } & Frekuensi & Persentase \\
\hline 1 & Meningkatkan hasil belajar siswa & 11 & 91,7 \\
\hline 2 & $\begin{array}{l}\text { Meningkatkan kemampuan dalam merancang pembelajaran dan } \\
\text { peningkatan hasil belajar siswa }\end{array}$ & 1 & 8,3 \\
\hline \multicolumn{1}{c}{ Jumlah } & 12 & $100 \%$ \\
\hline
\end{tabular}

Meta Analisis Berdasarkan Model, Strategi dan Media

Adapun penelitian dalam pembelajaran tematik menggunakan model, strategi dan media berikut:

Tabel 2. Model, Strategi dan Media

\begin{tabular}{clccc}
\hline No. & & Model, Strategi dan Media & Frekuensi & Persentase \\
\hline 1 & PBL & 3 & 25 \\
\hline 2 & SQ3R & 1 & 8,3 \\
\hline 3 & Discovery Learning & 1 & 8,3 \\
\hline 4 & CTL & 1 & 8,3 \\
\hline 5 & Picture and Picture & 1 & 8,3 \\
\hline 6 & Example to example & 1 & 8,3 \\
\hline 7 & Role Playing & 2 & 16,9 \\
\hline 8 & Media Komik & 1 & 8,3 \\
\hline 9 & Media lainnya & 1 & 8,3 \\
\hline & & 12 & $100 \%$ \\
\hline
\end{tabular}

\section{Meta Analisis Berdasarkan Analisis Data}

Analisis data yang digunakan dalam penelitian peningkatan hasil belajar siswa dalam pembelajaran tematik adalah deskriptif kuantitatif.

\section{Meta Analisis Berdasarkan Populasi/Sampel Data}

Populasi/sampel yang digunakan dalam penelitian peningkatan hasil belajar siswa dalam pembelajaran tematik adalah siswa SD dari berbagai tingkatan kelas, sebagaimana terlihat pada tabel berikut:

Tabel 3. Populasi/Sampel Data

\begin{tabular}{clccc}
\hline No. & & Model, Strategi dan Media & Frekuensi & Persentase \\
\hline 1 & Kelas I & 3 & 25 \\
\hline 2 & Kelas II & 1 & 8,3 \\
\hline 3 & Kelas III & 2 & 16,7 \\
\hline
\end{tabular}




\begin{tabular}{clccc}
\hline 4 & Kelas IV & 3 & 25 \\
\hline 5 & Kelas V & 3 & 25 \\
\hline & & Jumlah & 12 & $100 \%$ \\
\hline
\end{tabular}

\section{Meta Analisis Berdasarkan Peningkatan Hasil Belajar}

Hasil penelitian-penelitian terhadap upaya peningkatan hasi belajar siswa dalam pembelajan tematik, ditunjukkan dalam tabel berikut:

Tabel 4. Peningkatan Hasil Belajar

\begin{tabular}{ccc}
\hline No. & Peningkatan Hasil Belajar & Frekuensi \\
\hline 1 & 5.57 & 1 \\
\hline 2 & 18 & 2 \\
\hline 3 & 14 & 2 \\
\hline 4 & 28 & 1 \\
\hline 5 & 13 & 1 \\
\hline 6 & 5 & 1 \\
\hline 7 & 7 & 1 \\
\hline 8 & 26 & 1 \\
\hline 9 & 6 & 1 \\
\hline 10 & 11 & 1 \\
\hline & Jumlah & 12 \\
\hline
\end{tabular}

Selain peningkatan hasil belajar, berupa kemampuan kognitif siswa, peningkatan hasil belajar terjadi juga dalam bentuk kemampuan sosial, kemampuan memahami permainan, kemampuan pengambilan keputusan dan transfernya dalam sebuah permainan.

\section{Pembahasan}

Berdasarkan tinjuan terhadap hasil penelitian, secara umum didapatkan beberapa data bahwa untuk meningkatkan hasil belajar siswa pada pembelajaran tematik dapat dilakukan dalam berbagai model, strategi dan media pembelajaran. Penerapan berbagai model, strategi dan media pembelajaran dapat meningkatkan hasil belajar kognitif dan memberikan dampak positif sebagai berikut: 1) siswa mampu menghubungkan antara keterampilan teknis yang dilatihkan dalam pembelajaran diaplikasikan dalam permainan; 2) siswa terlibat secara penuh dalam pembelajaran, sehingga mempermudah tercapainya tujuan pembelajaran; 3) meningkatkan motivasi dan kegembiraan siswa dalam proses belajar mengajar; 4) siswa mampu meningkatkan kemampuan pengambilan keputusan, terlihat dari beberapa aspek dalam penelitian yang diamati yaitu: (a) kemampuan pengambilan keputusan eksekusi, (b) transfer keterampilan dalam praktek, (c) pemahaman taktik yang semakin berkembang, pengetahuan procedural. Selain itu, ada satu hal yang diamati peningkatannya yaitu kemampuan sosial yang dilakukan, perbaikan dalam keterlibatan siswa dalam pembelajaran/permainan, pengambilan keputusan, siswa yang mempunyai kemampuan baik dalam bermain, lebih cepat berkembang kemampuannya dengan materi yang dikemas dalam berbagai model, strategi dan media.

\section{SIMPULAN}

Berdasarkan hasil dan pembahasan penelitian, disimpulkan bahwa pembelajaran tematik dapat diajarkan dengan berbagai model, strategi, dan media pembelajaran, sehingga dapat meningkatkan hasil belajar siswa SD. Oleh karena itu, pembelajaran tematik yang dikemas dalam aktivitas pembelajaran taktik secara kognitif berperan dalam meningkatkan kemampuan berpikir siswa, kemampuan pengambilan keputusan, serta transfer dalam sebuah permainan.

\section{REFERENSI}

Badriah, Siti. 2016. Pembelajaran Tematik Menggunakan Media Video SCRIBE Pada Siswa Kelas IV Sekolah Dasar. Jurnal Elementary Vol. 7 No.1 January-Juni 2016. 
Diana, Peggy P. 2017. Meningkatkan Hasil Pembelajaran Tematik Kelas I B SD Negeri Jetis I melalui Picture and Picture. Jurnal Ilmiah Guru "COPE”, No. 01 XXI/Mei 2017.

Fatmawati. 2017. Peningkatan Hasil Belajar Pembelajaran Tematik pada Tema Lingkungan Menggunakan Model Pembelajaran Example Non Example di Kelas III SD N 06 Pekan Selasa Kec. Pauh Duo Kab. Solok Selatan. Jurnal Menara Ilmu, Vol. XI Jilid 2 No. 74 Januari 2017.

Fogarty, Robin. 1991. The Mindful School: How to Integrated the Curricula. Pallatine, Illionis: IRI/Skylight Publishing, Inc.

Fransiska, Faberta KS. 2018. Peningkatan Hasil Belajar Siswa SD pada Pembelajaran Tematik melalui Penerapan Model Pembelajaran Role Playing. Jurnal Satya Widya, Vol. 34 No.1 Juni 2018.

Hajar, Ibnu. 2013. Panduan Lengkap Kurikulum Tematik untuk SD/MI. Yogyakarta: Diva Press.

Helmina, Siagian. 2016. Peningkatan Hasil Belajar Tematik Model Pembelajaran Contextual Teaching and Learning Siswa Kelas II SD Negeri 163086 Tebing Tinggi. Jurnal ESJ, Vol. 5 No. 1 Juni 2016.

Maesaroh, 2018. Upaya Meningkatkan Hasil Belajar Tematik melalui Penerapan Model SQ3R pada Peserta Didik Kelas IV SD Negeri Mangunsari 02 Salatiga. Jurnal Humaniora, Vol. V No. 2 JuniDesember 2018.

Mezaoktrian. 2020. Peningkatan Hasil Belajar Siswa pada Pembelajaran Tematik Terpadu Menggunakan Metode Diskusi di Sekolah Dasar. Jurnal Pendidikan Tambosai, Vol. 4 No. 3 Tahun 2020.

Puri, Andari AP. 2014. Upaya Meningkatkan Hasil Belajar Pembelajaran Tematik Menggunakan Media Komik pada Siswa Kelas III SD Karanggondang Kabupaten Bantul Tahun Pelajaran 2013/2014. Jurnal Pendidikan Ke-SD-an, Vol. 1 No. 1 September 2014.

Raesa, Aldi Putri. 2020. Peningkatan Hasil Belajar Siswa Sekolah Dasar pada Pembelajaran Tematik Terpadu Menggunakan Model Problem Based Learning. JBES, Vol. 3 No. 2 Juli-Desember 2020.

Syosepina. 2020. Peningkatan Hasil Belajar Siswa pada Pembelajaran Tematik dengan Model Problem Based Learning di Kelas V SD Negeri 46 Parepare. Jurnal Al-Athfal, Vol. 2 No. 2 Maret 2020. 